\title{
Efficacy of Entomopathogenic Nematodes and Sprayable Polymer Gel Against Crucifer Flea Beetle (Coleoptera: Chrysomelidae) on Canola
}

\section{Authors: Frank B. Antwi and Gadi V. P. Reddy}

This is a pre-copyedited, author-produced PDF of an article accepted for publication in Journal of Economic Entomology following peer review. The version of record [Antwi, F.B., and Gaddi V. Reddy. "Efficacy of Entomopathogenic Nematodes and Sprayable Polymer Gel Against Crucifer Flea Beetle (Coleoptera: Chrysomelidae) on Canola." Journal of Economic Entomology (June 2016)] is available online at: https://dx.doi.org/10.1093/jee/tow140.

Made available through Montana State University's $\underline{\text { ScholarWorks }}$ 


\title{
Efficacy of Entomopathogenic Nematodes and Sprayable Polymer Gel Against Crucifer Flea Beetle (Coleoptera: Chrysomelidae) on Canola
}

\author{
Frank B. Antwi and Gadi V. P. Reddy \\ Western Triangle Agricultural Research Center, Montana State University, 9546 Old Shelby Rd., P.0. Box 656, Conrad, MT 59425 \\ (frank.antwi@montana.edu; reddy@montana.edu), and 1Corresponding author, e-mail: frank.antwi@montana.edu.
}

Received 26 April 2016; Accepted 27 May 2016

\begin{abstract}
The crucifer flea beetle, Phyllotreta cruciferae (Goeze), is a key pest of canola (Brassica napus L.) in the northern Great Plains of North America. The efficacies of entomopathogenic nematodes (Steinernema spp. and Heterorhabditis spp.), a sprayable polymer gel, and a combination of both were assessed on canola for flea beetle management. Plots were treated soon after colonization by adult flea beetles, when canola was in the cotyledon to one-leaf stage. Ten plants along a 3.6-m section of row were selected and rated at pre-treatment and 7 and $14 \mathrm{~d}$ post treatment using the damage-rating scheme advanced by the European Plant Protection Organization, where $1=0 \%, 2=2 \%, 3=5 \%, 4=10 \%$, and $5=25 \%$ leaf area injury. Under moderate flea beetle feeding pressure (1-3.3\% leaf area damaged), seeds treated with Gaucho 600 (Bayer CropScience LP Raleigh, NC) (imidacloprid) produced the highest yield $(843.2 \mathrm{~kg} / \mathrm{ha}$ ). Meanwhile, Barricade (Barricade International, Inc. Hobe Sound, FL) (polymer gel; 1\%) + Scanmask (BioLogic Company Inc, Willow Hill, PA) (Steinernema feltiae) resulted in the highest yields: $1020.8 \mathrm{~kg} / \mathrm{ha}$ under high $(2.0-5.3 \%$ leaf area damaged), and $670.2 \mathrm{~kg} / \mathrm{ha}$ at $\mathrm{ex}-$ tremely high (4.3-8.6 \% leaf area damaged) feeding pressure. Our results suggest that Barricade $(1 \%)+$ Scanmask ( $S$. feltiae) can serve as an alternative to the conventional chemical seed treatment. Moreover, Scanmask ( $S$. feltiae) can be used to complement the effects of seed treatment after its protection has run out.
\end{abstract}

Key words: Canola, Phyllotreta cruciferae, entomopathogenic nematode, sprayable polymer gel, leaf area injury

In North America, canola (Brassica napus L.; Brassicales, Brassicaceae) is a major oilseed crop, grown especially in the Northern Great Plains of the United States and the prairies of Canada (Brown 1967, Burgess 1977, Lamb 1984, Thomas 2003). The crucifer flea beetle, Phyllotreta cruciferae (Goeze) (Coleoptera, Chrysomelidae), is an economically important pest of canola in this region (Brown 1967, Burgess 1977, Lamb 1984, Thomas, 2003). Adult flea beetles emerge from overwintering sites in spring as air temperatures reach $15-20^{\circ} \mathrm{C}$ (Lamb 1983). Overwintered adults initially feed on brassicaceous weeds, and as the crop emerges, beetles move into canola fields, where they immediately begin to feed on young cotyledons and true leaves, stems, and pods (Lamb 1988, Thomas 2003). The larval stages contribute to yield losses during summer months by feeding on plant roots, root hairs, and tap roots of seedlings, and root damage reduces yield of about 5\% (Thomas 2003). Yield losses due to $P$. cruciferae feeding are estimated as tens of millions of U.S. dollars annually in the region (Burgess 1977, Lamb and Turnock 1982, Madder and Stermeroff 1988, Thomas 2003).

Phyllotreta cruciferae management is directed against adults in early spring when canola seedlings are vulnerable to flea beetle injury (Thomas 2003). Conventional control methods are chemical seed treatments or foliar sprays (Lamb and Turnock 1982, Antwi et al. 2007, Reddy et al. 2014). The majority of canola acreage in the Northern Great Plains is planted with insecticide-treated seed, as foliar chemical insecticides are only effective against $P$. cruciferae within a narrow window of opportunity before eggs have been laid in the soil (Turnock and Turnbull 1994, Glogoza et al. 2002, Tangtrakulwanich et al. 2014). This near uniform reliance on chemical insecticide-based pest management increases the risk of development of pesticide resistance. To help avoid this problem, entomopathogenic nematodes (EPNs), which are a group of nematodes that are lethal to many important insect pests, offer an alternative treatment regimen and may be used alone or in combination with reduced rates of conventional insecticides (Koppenhöffer and Kaya 1998). Concern over development of resistance and damage to pollinators and other beneficial insects makes the evaluation of alternative controls for P. cruciferae a current priority (Antwi et al. 2007, Reddy et al. 2014).

Ecorational insecticides are products that are likely to do minimal harm to nontarget organisms or the environment (Ware 1989). Ecorational insecticides have been shown to be effective against many insect pests (Hajek et al. 1987, Miranpuri et al. 1992, 
Miranpuri and Khachatourians 1995, Sparks et al. 1999, Xu et al. 2010), and they may have potential value in $P$. cruciferae management. Because ecorational insecticides' modes of action are very different from those of chemical insecticides (Sparks et al. 2001, Thompson et al. 2000), they can be used to slow down or prevent the development of insecticide resistance (Liu and Stansly 1995, Copping and Menn 2000). EPNs are persistent, they recycle inside the host, and inundative application may provide short-term control of pests with few or no deleterious effects on nontarget organisms (Rosell et al. 2008). They are used where chemical insecticides fail (e.g., in soil, or in boring insect pest galleries) or insecticide resistance develops (Ehlers 2001, Rosell et al. 2008). Because EPNs actively search for hosts, they have special value in the management of soil-dwelling pests such as flea beetles in Brassica crops (Grewal et al. 2005, Trdan et al. 2008, Wei et al. 1992). According to Kakizaki (2004), treatment of radish roots with Sternenema capocapsae (Weiser) (at 250,000-500,000 infective juvenile nematodes/ $\mathrm{m}^{2}$ ) reduced Phyllotreta striolata (F.) (Coleoptera: Chrysomelidae) damage by 33 to $80 \%$. EPNs in the genera Steinernema and Heterorhabditis can be used to manage many insect pests as biological control agents (Shapiro-llan et al. 2002, Shapiro-llan and Cottrell 2006, Grewal et al. 2005). However, ultraviolet radiation and desiccation effects can be a limiting factor for efficacy of EPNs at above-ground applications (Shappiro-Ilan et al. 2006, Glazer 1992). Shapiro-llan et al. $(2010,2016)$ concluded that EPNS treatments followed by a sprayable polymer gel application or as single spray can enhance the management of lesser peachtree borer, Synanthedon pictipes (Grote and Robinson) (Lepidoptera: Sesiidae) and other above-ground pests. Therefore, the use of sprayable gel in this study is meant to protect EPNs from harmful environmental conditions (ultraviolet radiation, desiccation). According to Koppenhöffer et al. (2000), various studies have shown that EPNs efficacy can be improved with other pathogens for white grubs (Coleoptera: Scarabaeidae) management. According to Thurston et al. (1993, 1994), EPNs and Bacillus popilliae Dutky (the Japanese beetle pathogen) (Bacillales: Paenibacillaceae) combination is only feasible in high economic threshold situations for long-term management. Moreover, EPNs and Bacillus thuringiensis Berliner Buibui strain (Bacillales: Bacillaceae) combination is only feasible for scarab species that are susceptible to this bacterium (Koppenhöfer and Kaya 1997, Koppenhöfer et al. 1999). However, due to limitations with these combinations, EPNs combined with chloronicotinyl insecticide (imidacloprid) would be more efficient with wider applicability (Koppenhöffer and Kaya 1998). The objective of our study was to evaluate the effect of low rates of several species of EPNs, combinations of EPN species, combinations of EPNs and a sprayable polymer gel, and a combination of EPN and imidacloprid on $P$. cruciferae feeding injury to seedling canola and resulting yield.

\section{Materials and Methods}

\section{Study Sites}

Trials were conducted at three field locations: Western Triangle Agricultural Research Center (WTARC; 48 $18.627^{\prime} \mathrm{N}, 111^{\circ}$ $55.402^{\prime} \mathrm{W}$ ) in Conrad, Sweet Grass (48 $57.831^{\prime} \mathrm{N}, 111^{\circ} 40.801^{\prime}$ W), and Cutbank (48 $\left.50.22^{\prime} \mathrm{N}, 112^{\circ} 17.746^{\prime} \mathrm{W}\right)$, Montana, USA. Experimental plots were seeded on 13 April 2015 at WTARC, on 20 April 2015 at Sweet Grass, and on 30 May 2015 at Cutbank. HyClass canola seeds (WindField Solutions, LLC) were used for all three locations, at a rate of 12 seeds per $30 \mathrm{~cm}$ using a four-row plot drill with a row spacing of $30 \mathrm{~cm}$. The herbicide RT3 (a.i. glyphosate) was applied at a rate of $2.5 \mathrm{~L} / \mathrm{ha}$ before seeding. Fertilizers at an N, P, K, and S ratio of 134.5, 25.2, 61.6, and $22.4 \mathrm{~kg} / \mathrm{ha}$ and $\mathrm{N}, \mathrm{P}, \mathrm{K}$ ratio of $12.3,25.2$, and $0 \mathrm{~kg} / \mathrm{ha}$ were applied at the time of seeding. The trials were conducted under dryland (i.e., nonirrigated) conditions.

\section{Treatments}

Twelve treatments were used for the studies (Table 1): 1) Water, 2) Gaucho (imidacloprid), 3) Ecomask (Steinernema carpocapsae), 4) Hi (Heterorhabditis indica), 5) Scanmask (Steinernema feltiae), 6) Heteromask (Heterorhabditis bacteriophora), 7) Ecomask + Heteromask (S. carpocapsae $+H$. bacteriophora), 8) Ecomask + Scanmask (S. carpocapsae $+S$. feltiae), 9) Gaucho+Scanmask (imidacloprid $+S$. feltiae), 10) Barricade (Barricade polymer 4\%), 11) Barricade $2 \%+$ Scanmask (Barricade polymer $2 \%+S$. feltiae), and 12) Barricade + Scanmask (Barricade polymer $1 \%+$ S. feltiae).

Plot Design and Data Collection.

The plot design was a randomized complete block design. Plots sizes were 3.6 by $1.2 \mathrm{~m}$, with a buffer zone of $1.2 \mathrm{~m}$ to avoid crosscontamination due to spray drift. Treatments were replicated four times at each location. Treatments were applied to plots with a SOLO backpack sprayer (SOLO, Newport News, VA) calibrated at $816.89 \mathrm{~L} / \mathrm{ha}$, after arrival of flea beetles in plots when air temperatures were $14-20^{\circ} \mathrm{C}$, and canola was in the cotyledon or one- to two-leaf stage. Untreated plots sprayed with water served as the control. Before treatment applications (PT), each plot was rated for $P$. cruciferae feeding injury along one $3.6-\mathrm{m}$ section of row, by sampling 10 plants at $0.3-\mathrm{m}$ intervals. Phyllotreta cruciferae injury measurements were made by visual classification into the European Plant Protection Organization (EPPO) damage categories as $1=$ no damage; $2=$ up to $2 \%$ leaf area eaten; $3=3-10 \%$ leaf area eaten; $4=10-25 \%$ leaf area eaten; and $5=>25 \%$ leaf area eaten $(\mathrm{EPPO}$, 2004). The visual injury ratings were converted into percent leaf area injury (OEPP/EPPO, 2004), where $1=0 \% ; 2=2 \% ; 3=5 \%$; $4=10 \%$; and $5=25 \%$ leaf area injury. Duration of efficacy of treatments was determined by post-application ratings for $P$. cruciferae injury at 7 and $14 \mathrm{~d}$ after application of foliar insecticides ( 7 and 14 DPT). Feeding injury and yield from plots were evaluated to compare treatment effects. Plots were harvested on 5 August 2015 at WTARC, on 14 September 2015 at Sweet Grass, and on 3 October 2015 at Cutbank when $50 \%$ of the canola seeds were dark in color.

The canola crop was straight combined at $30 \%$ seed moisture, stored, and air dried for $7 \mathrm{~d}$ until the seeds were at $8-10 \%$ moisture. The seeds were then cleaned and weighed to determine the seed yield per plot (as kilograms per hectare) for each experimental unit between August and October 2015.

\section{Data Analysis}

Data were analyzed using multivariate analyses of covariance (SAS Institute 2015). Analyses of covariance were used to account for and eliminate effects of pre-foliar treatment ratings on change in P. cruciferae feeding injury across dates after treatments. Least square means (LSMEANs) was run following analysis of variance (SAS Institute 2015). Main and interaction effects of location by treatment on $P$. cruciferae feeding injury ratings and yields were determined using the PROC GLM procedure (PROC GLM, SAS Institute 2015).

Synergistic, additive, or antagonistic interactions between Gaucho (imidacloprid) and EPNs in the combined treatments were determined with a $\chi^{2}$ test (Finney 1964, Koppenhöffer and Kaya 1998, Koppenhöffer et al. 2002, McVay et al. 1977). Abbott 


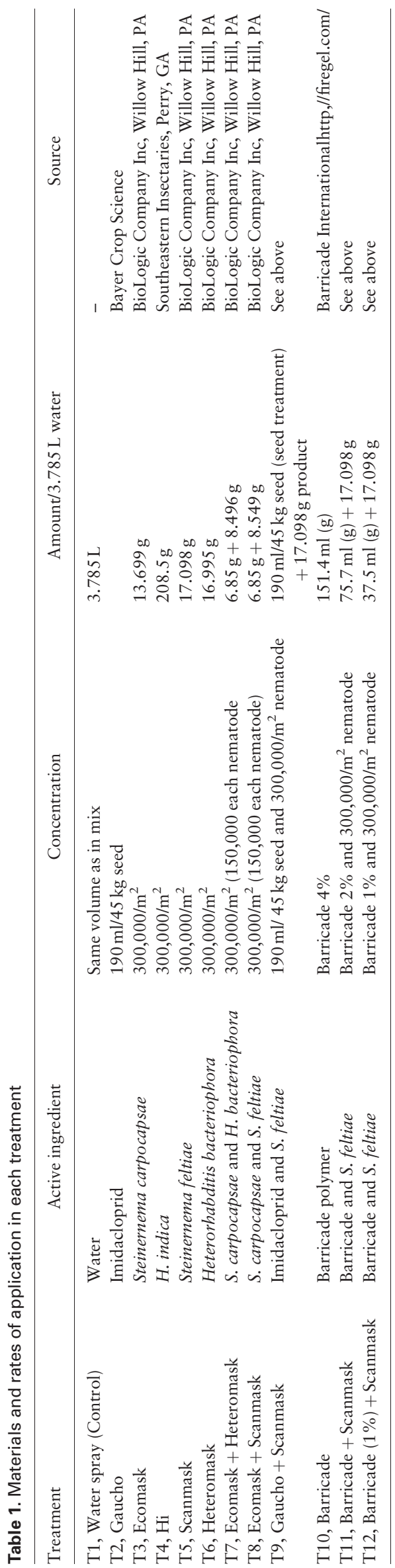

method (Abbott 1925) was used to correct for control leaf area damage. The expected additive proportional percentage leaf area damage Me for the nematode-Gaucho combinations was determined as $\mathrm{Me}=\mathrm{Mn}+\mathrm{Mi}(1-\mathrm{Mn})$, where $\mathrm{Mn}$ and $\mathrm{Mi}$ are the observed proportional percentage leaf area damage by EPNs and Gaucho (imidacloprid) alone, respectively. A $\chi^{2}$ test determined as $\left(\chi^{2}=\right.$ $\left.(\mathrm{Mni}-\mathrm{Me})^{2} / \mathrm{Me}\right)$ whereby $\mathrm{Mni}=$ the observed percentage leaf area damage for the EPN-Gaucho combinations was compared with the $\chi^{2}$ table value for $1 \mathrm{df}$. A nonadditive effect between two actives was suspected when the calculated $\chi^{2}$ value exceeded the table value (Finney 1964). A significant interaction was considered as synergistic when the difference Mni-Me had a positive value. When the difference $\mathrm{Mni}-\mathrm{Me}$ had a negative value, a significant interaction is considered antagonistic.

\section{Results}

Due to an especially cool spring, pest pressure at the research sites varied greatly among sites depending on sowing date. The average monthly weather parameters were precipitation $75.7 \mathrm{~mm}$, temperature $6.2^{\circ} \mathrm{C}$, and relative humidity $63.33 \%$ in April; precipitation $96 \mathrm{~mm}$, temperature $9.2^{\circ} \mathrm{C}$, and relative humidity $69.5 \%$ in May; and precipitation $136.5 \mathrm{~mm}$, temperature $17.5^{\circ} \mathrm{C}$, and relative humidity $68.4 \%$ in June (USDA-NRCS 2016). These conditions together with other biotic and abiotic factors caused P. cruciferae feeding pressure as determined by pre-treatment ratings to be moderate at WTARC (1-3.3\% leaf area injury), high at Sweet Grass (2$5.3 \%$ leaf area injury), and extremely high at Cutbank $(4.3-8.6 \%$ leaf area injury). Cotyledon and leaf injury did exceed the economic threshold of $15-20 \%$ leaf area defoliation across locations, especially at 14 DPT (Table 2; Tangtrakulwanich et al. 2014). In the water treatments, there were high levels of damage (WTARC: 5.9$15.6 \%$, Sweet Grass: $8.9-21.9 \%$, and Cutbank: $16.8-22.3 \%$ ) at 7 to 14 DPT. Under these conditions of pest pressure, it was not favorable to discern the value of the biorational treatments. Across the locations, the seed treatment Gaucho 600 resulted in the lowest leaf area injury at 7 to 14 DPT (Table 2).

Under moderate pest pressure (WTARC), Gaucho, the chemical seed treatment, was the most efficacious among the treatments. Among the treatment combinations or mixtures, Gaucho + Scanmask was the only treatment that resulted in a lower leaf area injury at 7 DPT. At 14 DPT, Gaucho 600 resulted in lower leaf area injury of $8.0 \%$. Phyllotreta cruciferae fed more on plots with Barricade + Scanmask than on those with Gaucho + Scanmask. The seed treatment Gaucho 600, with imidacloprid (a neonicotinoid) as the active ingredient, was fed on the least, likely because it is a broad-spectrum systemic insecticide acting as a contact and stomach poison on sucking and some biting insects (Sur and Stork 2003). It antagonizes the nicotinic acetylcholine receptor, resulting in paralysis and death of pest organisms (Bai et al. 1991, Nauen et al. 1998, Schmuck et al. 2003).

At high feeding pressure (Sweet Grass), Gaucho 600 and Gaucho + Scanmask resulted in the lowest $P$. cruciferae feeding pressure with leaf area defoliation of $4.7-12.4$ and $6.0-14.3 \%$, respectively, at 7 to 14 DPT.

Under extremely high P. cruciferae pressure (Cutbank), and at 7 DPT, none of the treatments performs better compared with the water control. However, at 14 DPT, only Gaucho 600 and Gaucho + Scanmask treatments perform better when compared with the water control. 
Table 2. Crucifer flea beetle Phyllotreta cruciferae feeding leaf area injury (as \% area damaged) to seedling canola plants treated with entomopathogenic nematodes and sprayable polymer gel in Montana at three time points, based on visual estimates

\begin{tabular}{|c|c|c|c|c|c|c|c|c|c|}
\hline \multirow[t]{3}{*}{ Treatment } & \multicolumn{3}{|c|}{ WTARC $^{a}$} & \multicolumn{3}{|c|}{ Sweet Grass } & \multicolumn{3}{|c|}{ Cutbank } \\
\hline & $\mathrm{PT}^{b}$ & $7 \mathrm{DPT}^{c}$ & $14 \mathrm{DPT}^{d}$ & PT & 7 DPT & 14 DPT & PT & $7 \mathrm{DPT}$ & $14 \mathrm{DPT}$ \\
\hline & \multicolumn{9}{|c|}{ Leaf area injury $(\%)$} \\
\hline Water & 2.5 & $5.9 \mathrm{abc}$ & $15.6 \mathrm{~b}$ & 5.3 & $8.9 \mathrm{bcd}$ & $21.9 \mathrm{~d}$ & 8.6 & $16.8 \mathrm{ab}$ & $22.3 \mathrm{c}$ \\
\hline Gaucho 600 & 2.0 & $3.1 \mathrm{a}$ & $8.0 \mathrm{a}$ & 2.0 & $4.7 \mathrm{a}$ & $12.4 \mathrm{a}$ & 4.5 & $14.3 \mathrm{a}$ & $13.2 \mathrm{a}$ \\
\hline Ecomask & 3.3 & $7.6 \mathrm{bcd}$ & $15.9 \mathrm{bc}$ & 2.7 & 7.4abc & $21.3 \mathrm{~cd}$ & 8.3 & $18.9 \mathrm{ab}$ & $19.6 \mathrm{bc}$ \\
\hline $\mathrm{Hi}$ & 2.1 & 11.3def & $15.1 b$ & 2.5 & $8.9 \mathrm{bcd}$ & $19.2 \mathrm{bc}$ & 5.2 & $15.6 \mathrm{ab}$ & $19.9 \mathrm{c}$ \\
\hline Scanmask & 1.9 & $14.7 \mathrm{f}$ & $19.2 \mathrm{c}$ & 3.3 & $9.7 \mathrm{~cd}$ & $20.9 \mathrm{~cd}$ & 7.1 & $15.7 \mathrm{ab}$ & $19.2 \mathrm{bc}$ \\
\hline Heteromask & 1.4 & $14.7 f$ & $19.2 \mathrm{c}$ & 4.1 & $9.8 \mathrm{~cd}$ & $18.9 \mathrm{bc}$ & 6.5 & $19.0 \mathrm{ab}$ & $21.3 \mathrm{c}$ \\
\hline Ecomask + Heteromask & 1.3 & $12.2 \mathrm{ef}$ & $19.2 \mathrm{c}$ & 3.5 & $8.2 \mathrm{bcd}$ & $20.2 \mathrm{bcd}$ & 7.9 & $20.2 \mathrm{~b}$ & $21.3 \mathrm{c}$ \\
\hline Ecomask + Scanmask & 1.7 & $9.8 \mathrm{de}$ & $15.3 \mathrm{~b}$ & 4.2 & $8.1 \mathrm{bcd}$ & $20.6 \mathrm{bcd}$ & 8.2 & $16.0 \mathrm{ab}$ & $19.6 \mathrm{bc}$ \\
\hline Gaucho + Scanmask & 1 & $5.8 \mathrm{ab}$ & $9.8 \mathrm{a}$ & 2.2 & $6.0 \mathrm{ab}$ & $14.3 \mathrm{a}$ & 4.3 & $14.2 \mathrm{a}$ & $16.5 b$ \\
\hline Barricade $(4 \%)$ & 1.4 & $9.8 \mathrm{cde}$ & $14.4 \mathrm{~b}$ & 3.8 & $9.7 \mathrm{~cd}$ & $18.2 \mathrm{~b}$ & 6.6 & $15.5 \mathrm{ab}$ & $20.6 c$ \\
\hline Barricade $(2 \%)+$ Scanmask & 1.7 & 10.0de & $15.9 \mathrm{bc}$ & 3.0 & $7.4 \mathrm{abc}$ & $18.2 \mathrm{~b}$ & 8.2 & $15.7 \mathrm{ab}$ & $20.6 c$ \\
\hline Barricade $(1 \%)+$ Scanmask & 1.9 & 10.1de & $16.4 \mathrm{bc}$ & 3.1 & $10.5 \mathrm{~d}$ & $19.2 \mathrm{bc}$ & 6.6 & $17.0 \mathrm{ab}$ & $19.9 \mathrm{c}$ \\
\hline
\end{tabular}

Means within a column followed by the same letter are not significantly different at $P<0.05$.

${ }^{a}$ WTARC, Western Triangle Agricultural Research Center.

${ }^{b} \mathrm{PT}$, pre-foliar application.

${ }^{c} 7$ DPT, days after foliar and granular application.

${ }^{d} 14$ DPT, days after foliar and granular application.

\section{Percentage Leaf Area Injury}

Generally at WTARC and Sweet Grass, Gaucho and Gaucho+ Scanmask treatments resulted in a lower percent leaf area injury at 7 to 14 DPT (Table 2).

At WTARC, the leaf area injury ranged from 1 to $3.3 \%$ at PT (Table 2). Except water and Gaucho + Scanmask treatments at 7 DPT, Gaucho had a significant leaf area injury of $3.1 \%$ compared with the other treatments (Table 2). Among the treatment combinations, Gaucho + Scanmask was the only one that resulted in a lower leaf area injury of $5.8 \%$ and this was not significant when compared with Gaucho and water (Table 2). At 14 DPT, Gaucho and Gaucho + Scanmask resulted in a significantly lower leaf area injury of 8.0 and $9.8 \%$, respectively (Table 2). The treatments Scanmask, Heteromask, and Ecomask + Heteromask had leaf area injuries that were significantly higher compared with the control.

At Sweet Grass, the leaf area injury varied from 2.0 to $5.3 \%$ at PT (Table 2). Treatment of canola with Gaucho 600 resulted in the lowest leaf area injury of $4.7 \%$ at 7 DPT compared with the water control (Table 2). At 14 DPT, Gaucho 600 (12.4\%) and Gaucho + Scanmask $(14.3 \%)$ had leaf area injury levels significantly lower than the rest of the treatments (Table 2). Except for Ecomask, Scanmask, Ecomask + Heteromask, and Ecomask + Scanmask, all treatments had leaf area injuries significantly lower than the water control (Table 2).

The leaf area injury at Cutbank ranged from 4.3 to $8.6 \%$ at PT (Table 2). At 7 DPT, Gaucho + Scanmask and Gaucho 600 treatments had leaf area injuries of 14.2 and $14.3 \%$, respectively (Table 2). At $14 \mathrm{DPT}$, Gaucho 600 (13.2\%) and Gaucho+Scanmask $(16.5 \%)$ were the only treatments that had a leaf area injury significantly lower than the water control (22.3\%; Table 2$)$.

\section{Effect of Treatments on Seed Yield}

Overall, yield $(F=2.69 ; \mathrm{df}=35,143 ; P<0.0001)$ and location $(F=28.97 ; \mathrm{df}=2,22 ; P<0.0001)$ effects were significantly different among treatments. However, overall treatment $(F=1.63$; $\mathrm{df}=11,22 ; P=0.1014)$ and location $\times$ treatment $(F=0.84 ; \mathrm{df}=2$, 22; $P=0.6704)$ effects were not significant.
Table 3. Canola seed yield after treatment of seedlings with entomopathogenic nematodes and sprayable gel in Montana

\begin{tabular}{llcl}
\hline Treatment & \multicolumn{3}{c}{ Location } \\
\cline { 2 - 4 } & WTARC $^{a}$ & $\begin{array}{c}\text { Sweet Grass } \\
\text { Yield }(\mathrm{kg} / \mathrm{ha})\end{array}$ & Cutbank \\
\hline Water & $354.8 \mathrm{~d}$ & $588.2 \mathrm{~b}$ & $427.1 \mathrm{ab}$ \\
Gaucho 600 & $843.2 \mathrm{a}$ & $810.6 \mathrm{ab}$ & $305.1 \mathrm{~b}$ \\
Ecomask & $620.0 \mathrm{c}$ & $778.1 \mathrm{ab}$ & $222.7 \mathrm{~b}$ \\
Hi & $804.0 \mathrm{ab}$ & $645.1 \mathrm{ab}$ & $405.8 \mathrm{~b}$ \\
Scanmask & $641.7 \mathrm{bc}$ & $699.4 \mathrm{ab}$ & $351.5 \mathrm{~b}$ \\
Heteromask & $669.1 \mathrm{abc}$ & $560.3 \mathrm{~b}$ & $403.9 \mathrm{~b}$ \\
Ecomask + Heteromask & $665.3 \mathrm{abc}$ & $701.6 \mathrm{ab}$ & $388.6 \mathrm{~b}$ \\
Ecomask + Scanmask & $801.8 \mathrm{ab}$ & $721.8 \mathrm{ab}$ & $358.0 \mathrm{~b}$ \\
Gaucho + Scanmask & $650.6 \mathrm{bc}$ & $761.6 \mathrm{ab}$ & $413.0 \mathrm{~b}$ \\
Barricade $(4 \%)$ & $758.3 \mathrm{abc}$ & $720.3 \mathrm{ab}$ & $357.9 \mathrm{~b}$ \\
Barricade $(2 \%)+$ Scanmask & $699.5 \mathrm{abc}$ & $604.5 \mathrm{~b}$ & $469.5 \mathrm{ab}$ \\
Barricade $(1 \%)+$ Scanmask & $739.5 \mathrm{abc}$ & $1020.8 \mathrm{a}$ & $670.2 \mathrm{a}$
\end{tabular}

Means within a column followed by the same letter are not significantly different at $P<0.05$.

${ }^{a}$ WTARC, Western Triangle Agricultural Research Center.

At WTARC, all treatments differ significantly from the water control (Table 3). Gaucho 600 resulted in the highest yield of $843.2 \mathrm{~kg} / \mathrm{ha}$ compared with Ecomask $(620.0 \mathrm{~kg} / \mathrm{ha})$, Scanmask $(641.7 \mathrm{~kg} / \mathrm{ha})$, and Gaucho+Scanmask (650.6 kg/ha; Table 3). Although $\mathrm{Hi}$ and Ecomask + Scanmask had yields of $804.0 \mathrm{~kg} / \mathrm{ha}$, and $801.8 \mathrm{~kg} / \mathrm{ha}$, respectively, none of the treatments had yields that were as good as Gaucho the chemical standard (Table 3).

At Sweet Grass, Barricade (1\%) + Scanmask resulted in the highest yield of $1020.8 \mathrm{~kg} / \mathrm{ha}$, and this was the only treatment that differed significantly from the water control (Table 3). None of the other treatments had yields that were significantly as better than Gaucho the chemical seed treatment (Table 3).

At Cutbank, Barricade $(1 \%)+$ Scanmask resulted in the highest yield of $670.2 \mathrm{~kg} / \mathrm{ha}$, and this did not differ significantly from the water control (Table 3). However, none of the other treatments had 
Table 4. Interaction between Gaucho and entomopathogenic nematodes (Ecomask, Hi, Scanmask, and Heteromask) against crucifer flea beetle Phyllotreta cruciferae at two time points in Montana

\begin{tabular}{|c|c|c|c|c|c|c|c|c|c|c|c|c|}
\hline \multirow[t]{3}{*}{ Treatment } & \multicolumn{12}{|c|}{ WTARC } \\
\hline & \multicolumn{6}{|c|}{$7 \mathrm{DPT}$} & \multicolumn{6}{|c|}{$14 \mathrm{DPT}$} \\
\hline & $\mathrm{Mn}^{a}$ & $\mathrm{Mi}^{b}$ & $\mathrm{Me}^{c}$ & $\mathrm{Mni}^{d}$ & $\mathrm{Mni}-\mathrm{Me}^{e}$ & $\begin{array}{c}(\mathrm{Mni}-\mathrm{Me})^{2} \\
/ \mathrm{Me}\end{array}$ & $\mathrm{Mn}$ & $\mathrm{Mi}$ & $\mathrm{Me}$ & Mni & Mni - Me & $\begin{array}{c}(\mathrm{Mni}-\mathrm{Me})^{2} \\
/ \mathrm{Me}\end{array}$ \\
\hline Gaucho 600 & -2.98 & -2.98 & -14.81 & -0.11 & 14.70 & -14.70 & -9.00 & -9.00 & -99.10 & -6.87 & 92.22 & -85.83 \\
\hline Ecomask & 1.81 & -2.98 & 4.21 & -0.11 & -4.31 & 4.31 & 0.36 & -9.00 & -5.45 & -6.87 & -1.42 & -0.37 \\
\hline $\mathrm{Hi}$ & 5.74 & -2.98 & 19.84 & -0.11 & -19.95 & 19.95 & -0.59 & -9.00 & -14.93 & -6.87 & 8.06 & -4.35 \\
\hline Scanmask & 9.35 & -2.98 & 34.20 & -0.11 & -34.31 & 34.31 & 4.27 & -9.00 & 33.67 & -6.87 & -40.54 & 48.82 \\
\hline Heteromask & 9.35 & -2.98 & 34.20 & -0.11 & -34.31 & 34.31 & 4.27 & -9.00 & 33.67 & -6.87 & -40.54 & 48.82 \\
\hline \multirow[t]{2}{*}{ Gaucho + Scanmask } & -0.11 & -2.98 & -3.40 & -0.11 & 3.29 & -3.29 & -6.87 & -9.00 & -77.76 & -6.87 & 70.89 & -64.62 \\
\hline & \multicolumn{12}{|c|}{ Sweet Grass } \\
\hline Gaucho 600 & -4.61 & -4.61 & -30.48 & -3.18 & 27.29 & -11.46 & -12.16 & -12.16 & -172.29 & -9.73 & 162.56 & -153.38 \\
\hline Ecomask & -1.65 & -4.61 & -13.85 & -3.18 & 10.67 & -59.40 & -0.77 & -12.16 & -22.28 & -9.73 & 12.55 & -7.07 \\
\hline $\mathrm{Hi}$ & 0 & -4.61 & -4.61 & -3.18 & 1.43 & -254.15 & -3.46 & -12.16 & -57.67 & -9.73 & 47.94 & -39.85 \\
\hline Scanmask & 0.88 & -4.61 & 0.32 & -3.18 & -3.50 & 4371.14 & -1.28 & -12.16 & -29.02 & -9.73 & 19.29 & -12.82 \\
\hline Heteromask & 0.99 & -4.61 & 0.93 & -3.18 & -4.12 & 1513.27 & -3.84 & -12.16 & -62.73 & -9.73 & 53.00 & -44.78 \\
\hline \multirow[t]{2}{*}{ Gaucho + Scanmask } & -3.18 & -4.61 & -22.47 & -3.18 & 19.29 & -24.58 & -9.73 & -12.16 & -140.26 & -9.73 & 130.53 & -121.48 \\
\hline & \multicolumn{12}{|c|}{ Cutbank } \\
\hline Gaucho 600 & -3.01 & -3 & -15.04 & -3.13 & 11.91 & -237.40 & -11.71 & -11.71 & -160.59 & -7.47 & 153.12 & -146.01 \\
\hline Ecomask & 2.52 & -3 & 7.10 & -3.13 & -10.23 & 809.92 & -3.48 & -11.71 & -55.88 & -7.47 & 48.42 & -41.95 \\
\hline $\mathrm{Hi}$ & -1.44 & -3 & -8.78 & -3.13 & 5.66 & -470.85 & -3.09 & -11.71 & -50.98 & -7.47 & 43.51 & -37.14 \\
\hline Scanmask & -1.32 & -3 & -8.30 & -3.13 & 5.18 & -503.59 & -3.99 & -11.71 & -62.43 & -7.47 & 54.96 & -48.39 \\
\hline Heteromask & 2.64 & -3 & 7.59 & -3.13 & -10.71 & 765.53 & -1.29 & -11.71 & -28.07 & -7.47 & 20.61 & -15.13 \\
\hline Gaucho + Scanmask & -3.13 & -3 & -15.52 & -3.13 & 12.40 & -227.35 & -7.47 & -11.71 & -106.60 & -7.47 & 99.14 & -92.19 \\
\hline
\end{tabular}

\footnotetext{
${ }^{a}$ Observed proportional percentage leaf area damage caused by nematodes alone.

${ }^{b}$ Observed proportional percentage leaf area damage caused by Gaucho (imidacloprid) alone.

${ }^{c}$ Expected additive proportional percentage leaf area damage for the nematode-Gaucho (imidacloprid) combinations.

${ }^{d}$ Observed proportional percentage leaf area damage for the nematode-Gaucho (imidacloprid) combinations.

${ }^{e}$ Interaction between treatments: Antagonistic (Mni - Me =a negative value), Nonadditive effect (synergistic or antagonistic; $\chi>3.841$ ), (Synergistic (Mni $\mathrm{Me}=$ a positive value $)$.
}

yields that were significantly better than Gaucho the chemical seed treatment (Table 3).

\section{Discussion}

In general, $P$. cruciferae fed less on plots treated with Gaucho+ Scanmask, and Gaucho 600 at 7 to 14 DPT. Moreover, the interaction of Gaucho + Scanmask was synergistic (Table 4). This agrees with observations that EPNs and imidacloprid interacted synergistically on Popillia japonica Newman (white grub) (Coleoptera: Scarabaedae) mortality (Koppenhöfer and Kaya 1998; Koppenhöfer et al. 2000a, 2002), where a general reduction in mobility appeared to be a major factor responsible for this synergistic interaction (Koppenhöfer et al. 2000b). A general disruption of nerve function from imidacloprid seems to enhance the attachment of juvenile EPN to the host and subsequent penetration (Koppenhöfer et al. 2000a).

Under moderate, high, and extremely high $P$. cruciferae feeding pressure in our study, Gaucho + Scanmask was the only treatment that had leaf area injury rates on par with Gaucho 600 (imidacloprid). EPNs applied alone or in combination with other EPNs were not effective, possibly due to ultraviolet radiation or desiccation (Shapiro-llan et al. 2002), and that above-ground application of EPNs could be improved by protecting the EPNs from harmful environmental conditions (Glazer et al. 1992, Baur et al. 1997, Head et al. 2004, Schroer and Ehlers 2005, Shapiro-llan et al. 2006). Moreover, the nematode products were obtained from different companies, and hence, production method and formulation might also be among the factors that affected their efficacy. Notwithstanding this, it is reasonable to use EPNs from different producers, as the growers will also purchase EPNs from different sources.

Under moderate P. cruciferae feeding pressure, Gaucho 600 resulted in the highest yield of $843.2 \mathrm{~kg} / \mathrm{ha}$ at WTARC, while Barricade $(1 \%)+$ Scanmask resulted in the highest yield of $1020.8 \mathrm{~kg} / \mathrm{ha}$ at Sweet Grass and $670.2 \mathrm{~kg} / \mathrm{ha}$ at Cutbank. Under high and extremely high $P$. cruciferae feeding pressure at Sweet Grass and Cutbank, the Barricade $(1 \%)+$ Scanmask treatment had the highest yields, suggesting that when the seed treatment protection period is exceeded, Barricade and Scanmask ( $S$. feltiae) can be used as a complement to Gaucho to reduce P. cruciferae feeding and subsequent yield losses. Based on yield, EPNs applied alone as single control agent or in combination with other EPNs were not effective, especially under high and extremely high $P$. cruciferae feeding pressure. Similar to our findings, Shapiro-llan et al. (2010, 2015, 2016) found that the sprayable gel Barricade significantly enhanced the efficacy of EPNs ( $S$. feltiae, S. carpocapsae) for controlling S. pictipes and Synanthedon exitiosa (Say) (Lepidoptera: Sesiidae).

The data indicate that Barricade $(1 \%)+$ Scanmask can serve as alternative to the seed treatment. Moreover, Scanmask can be used to complement the seed treatment when the protection period is exceeded. However, net returns on the use of these biopesticides need to be ascertained. 


\section{Acknowledgments}

We would like to thank (United States Department of Agriculture) USDANational Institute of Food and Agriculture Hatch (Accession\#MONB00859) and Professional Development Program of the USDA-Western Sustainable Agriculture Research and Education project \#2014-38640-22175/Utah State University sub award \# 140867038 for funding. Any opinions, findings, conclusions, or recommendations expressed in this publication are those of the authors and do not necessarily reflect the view of the National Institute of Food and Agriculture (NIFA) of the United States Department of Agriculture (USDA). We would also like to thank John Miller, Amber Ferda, Julie Prewett, Judisch Krystal, and Dowson Berg for assistance with field work.

\section{References Cited}

Abbott, W. S. 1925. A method for computing the effectiveness of an insecticide. J. Econ. Entomol. 18: 265-267.

Antwi, F. B., D. L. Olson, and J. J. Knodel. 2007. Comparative evaluation and economic potential of ecorational versus chemical insecticides for crucifer flea beetle (Coleoptera: Chrsomelidae) management in canola. J. Econ. Entomol. 100: 710-716.

Bai, D., S.C.R. Lummis, W. Leicht, H. Breer, and D. B. Sattelle. 1991. Actions of imidacloprid and a related nitromethylene on cholinergic receptors of an identified insect motor neuron. Pestic. Sci. 33: 197-204.

Baur, M. E., H. K. Kaya, R. Gaugler, and B. E. Tabashnik. 1997. Effects of adjuvants on entomopathogenic nematode persistence and efficacy against Plutella xylostella. Biocontrol Sci. Technol. 7: 513-525.

Burgess, L. 1977. Flea beetles (Coleoptera, Chrysomelidae) attacking rape crops in the Canadian prairie provinces. Can. Entomol. 109: 21-32.

Brown, W. J. 1967. Notes on the extralimital distribution of some species of Coleoptera. Can. Entomol. 99: 85-93.

Copping, L. G., and J. J. Menn. 2000. Biopesticides, a review of their action, applications and efficacy. Pest Manag. Sci. 56: 651-676.

Ehlers, R. 2001. Mass production of entomopathogenic nematodes for plant protection. Appl. Microbiol. Biotechnol. 56: 623-633.

Finney, D. J. 1964. Probit Analysis. Cambridge University Press, London.

Glazer, I. M. 1992. Survival and efficacy of Steinernema carpocapsae in an exposed environment. Biocontrol Sci. Technol. 2: 101-107.

Glazer, I., M. Klein, A. Navon, and Y. Nakache. 1992. Comparison of efficacy of entomopathogenic nematodes combined with antidesiccants applied by canopy sprays against three cotton pests (Lepidoptera, Noctuidae). J. Econ. Entomol. 85: 1636-1641.

Glogoza, P., M. McMullen, R. Zollinger, A. Thostenson, T. Dejong, W. Meyer, N. Schauer, and J. Olson. 2002. Pesticide use and pest management practices for major crops in North Dakota 2000. North Dakota State Univ. Coop. Ext. Serv. Publ. ER-79. North Dakota State University, Fargo, ND.

Grewal, P. S., R. U. Ehlers, and D. I. Shapiro-llan. 2005. Critical issues and research needs for expanding the use of nematodes in biocontrol, pp. 479-490. In P. S. Grewal, R-U. Ehlers, and D. I. Shapiro-llan (eds.), Nematodes as biocontrol agents. CABI, New York, NY.

Hajek, A. E., R. S. Soper, D. W. Roberts, T. E. Anderson, K. D. Biever, D. N. Ferro, R. A. Leburn, and R. H. Storch. 1987. Foliar applications of Beauveria bassiana (Balsamo) for control of the Colorado potato beetle, Leptinotarsa decemllineata (Say) (Coleoptera, Chrysomelidae), an overview of pilot test results from the northern United States. Can. Entomol. 119: 959-974.

Head, J., A. J. Lawrence, and K.F.A. Walters. 2004. Efficacy of the entomopathogenic nematode, Steinernema feltiae, against Bemisia tabaci in relation to plant species. J. Appl. Entomol. 128: 543-547.

Kakizaki, M. 2004. Control effect of the striped flea beetle, Phyllotreta striolata (Fabricius), by application of the entomopathogenic nematode, Steinernema carpocapsae, on a Japanese radish. Annu. Rep. Soc. Plant Prot. North Japan. 55: 221-225.

Koppenhöfer, A. M., and H. K. Kaya. 1997. Additive and synergistic interaction between entomopathogenic nematodes and Bacillus thuringiensis for scarab grub control. Biol. Control 8: 131-137.

Koppenhöfer, A. M., and H. K. Kaya. 1998. Synergism of imidacloprid and entomopathogenic nematodes, a novel approach to white grub control in turfgrass. J. Econ. Entomol. 91: 618-623.
Koppenhöfer, A. M., H. Y. Choo, H. K. Kaya, D. W. Lee, and W. D. Gelernter. 1999. Increased field and greenhouse efficacy with combinations of an entomopathogenic nematode and Bacillus thuringiensis against scarab grubs. Biol. Control 14: 37-44.

Koppenhöfer, A. M., P. S. Grewal, and H. K. Kaya. 2000a. Synergism of imidacloprid and entomopathogenic nematodes against white grubs, the mechanism Entomol. Exp. Appl. 94: 283-293.

Koppenhöfer, A. M., I. M. Brown, R. Gaugler, P. S. Grewal, H. K. Kaya, and M. G. Klein. 2000b. Synergism of entomopathogenic nematodes and imidacloprid against white grubs, greenhouse and field evaluation. Biol. Control 19: 245-251.

Koppenhöfer, A. M, R. S. Cowles, E. A. Cowles, E. M. Fuzy, and L. Baumgartner. 2002. Comparison of neonicotinoid insecticides as synergists for entomopathogenic nematodes. Biol. Control 24: 90-97.

Lamb, R. J. 1983. Phenology of flea beetle (Coleoptera, Chrysomelidae) flight in relation to their invasion of canola fields in Manitoba. Can. Entomol. 115: 1493-1502.

Lamb, R. J. 1984. Effects of flea beetles, Phyllotreta cruciferae (Coleoptera, Chrysomelidae), on the survival, growth, seed yield and quality of canola, rape and yellow mustard. Can. Entomol. 116: 269-280.

Lamb, R. J. 1988. Assessing the susceptibility of crucifer seedlings to flea (Phyllotreta spp.) damage. 1988. Can. J. Plant. Sci. 68: 85-93.

Lamb, R. J., and W. J. Turnock. 1982. Economics of insecticidal control of flea beetles (Coleoptera, Chrysomelidae) attacking rape in canola. Can. Entomol. 114: 827-840.

Liu, T., and P. A. Stansly. 1995. Toxicity and repellency of some biorational insecticides to Bemisia argentifolii on tomato plants. Entomol. Exp. Appl. 74: 137-143.

Madder, J., and M. Stermeroff. 1988. The economics of insect control on wheat, corn, and canola in Canada, 1980-1985. Bull. Entomol. Soc. Can. 20: 1-22.

McVay, J. R., R. T. Gudauskas, and J. D. Harper. 1977. Effects of Bacillus thuringiensis nuclear- polyhedrosis virus mixtures on Trichoplusia ni larvae. J. Invertebr. Pathol. 29: 367-372.

Miranpuri, G. S., and G. G. Khachatourians. 1995. Entomopathogenicity of Beauveria bassiana toward flea beetles, Phyllotreta cruciferae Goeze (Coleoptera, Chrysomelidae). J. Appl. Entomol. 119: 167-170.

Miranpuri, G. S., M. S. Ubhi, M. King, and G. G. Khachatourians. 1992. Efficacy of different strains of entomopathogenic fungus, Beauveria bassiana against blister beetle, Lytta nuttali Say, pp. 91-92. In Proceedings, National Symposium Research Advance on Integrated Pest Management, October 1992, Punjab Agricultural University, Ludhiana, India. India Society for Advancement of Insect Science, Ludhiana, India.

Nauen, R., B. Tollo, K. Tietjen, and A. Elbert. 1998. Antifeedant effect, biological efficacy and high affinity binding of imidacloprid to acetylcholine receptors in Myzus persicae and Myzus nicotianae. Pestic. Sci. 51: 52-56.

OEPP/EPPO. 2004. Efficacy evaluation of insecticides. Phyllotreta spp. on rape, pp. 242-244. OEPP/EPPO Bull. Pp 1/218.

Reddy, G.V.P., K. Tangtrakulwanich, S. Wu, J. H. Miller, V. L. Ophus, and J. Prewett. 2014. Sustainable management tactics for control of Phyllotreta cruciferae (Coleoptera, Chrysomelidae) on canola in Montana. J. Econ. Entomol. 107: 661-666.

Rosell, G., C. Quero, J. Coll, and A. Guerrero. 2008. Biorational insecticides in pest management. J. Pestic. Sci. 33: 103-121.

SAS Institute Inc. 2015. 9.2 In-Database Products, User's Guide, fifth ed. SAS Publishers, Cary, NC.

Schmuck, R., R. Nauen, and U. Ebbinghaus-Kintscher. 2003. Effects of imidacloprid and common plant metabolites of imidacloprid in the honeybee, toxicological and biochemical considerations, pp. 27-34. In C. Porrini, and L. Bortolotti (eds.), Proceedings of the 8th international symposium "hazards of pesticides to bees”, September 4-6, 2002, Bologna, Italy. Bull. Insectol. 56.

Schroer, S., and R.-U. Ehlers. 2005. Foliar application of the entomopathogenic nematode Steinernema carpocapsae for biological control of diamondback moth larvae (Plutella xylostella). Biol. Control 33: 81-86.

Shapiro-llan, D. I., and T. E. Cottrell. 2006. Susceptibility of the lesser peachtree borer (Lepidoptera, Sesiidae) to entomopathogenic nematodes under laboratory conditions. Environ. Entomol. 35: 358-365. 
Shapiro-llan, D. I., D. H. Gouge, and A. M. Koppenhöfer. 2002. Factors affecting commercial success, case studies in cotton, turf and citrus, pp. 333-356. In R. Gaugler (ed.), Entomopathogenic Nematology. CABI, New York, NY.

Shapiro-llan, D. I., D. H. Gouge, S. J. Piggott, and J. P. Fife. 2006. Application technology and environmental considerations for use of entomopathogenic nematodes in biological control. Biol. Control 38: 124-133.

Shapiro-llan, D. I., T. E. Cottrell, R. F. Mizell III, D. L. Horton, B. Behle, and C. Dunlap. 2010. Efficacy of Steinernema carpocapsae for control of the lesser peachtree borer, Synanthedon pictipes, improved aboveground suppression with a novel gel application. Biol. Control 54: 23-28.

Shapiro-llan, D. I., T. E. Cottrell, R. F. Mizell III, D. L. Horton, and A. Zaid. 2015. Field suppression of the peachtree borer, Synanthedon exitiosa, using Steinernema carpocapsae, effects of irrigation, a sprayable gel and application method. Biol. Control. 82: 7-12.

Shapiro-llan, D. I., T. E. Cottrell, R. F. Mizell III, and D. L. Horton. 2016. Efficacy of Steinernema carpocapsae plus fire gel applied as a single spray for control of the lesser peachtree borer, Synanthedon pictipes. Biol. Control 94: 33-36.

Sparks, T. C., G. D. Thompson, H. A. Kirst, M. B. Hertlein, J. S. Mynderse, J. R. Turner, and T. V. Worden. 1999. Fermentation-derived insect control agents the spinosyns, pp. 171-188. In F. R. Halland, and J. J. Menn, (eds.), Biopesticides, use and delivery. Humana Press, Totowa, NJ.

Sparks, T. C., G. D. Crouse, and G. Durst. 2001. Natural products as insecticides, the biology, biochemistry and quantitative structure-activity relationships of spinosyns and spinosoids. Pest Manag. Sci. 57: 896-905.

Sur, R., and A. Stock. 2003. Uptake, translocation and metabolism of imidacloprid in plants. Bull. Insectol. 56: 35-40.

Tangtrakulwanich, K., G.V.P. Reddy, S. Wu, J. H. Miller, V. L. Ophus, and J. Prewett. 2014. Developing nominal threshold levels for Phyllotreta cruciferae (Coleoptera: Chrysomelidae) damage on canola in Montana, USA. Crop Prot. 66: 8-13.

Thomas, P. 2003. Canola growers manual. Canola Council of Canada, Winnipeg, Manitoba, Canada.

Thompson, G. D., R. Dutton, and T. C. Sparks. 2000. Spinosad a case study, an example from a natural product discovery programme. Pest Manag. Sci. 56: 696-702.

Thurston, G. S., H. K. Kaya, T. M. Burlando, and R. E. Harrison. 1993. Milky disease bacterium as a stressor to increase susceptibility of scarabaeid larvae to an entomopathogenic nematode. J. Inverte. Pathol. 61: 167-172.

Thurston, G. S., H. K. Kaya, and R. Gaugler. 1994. Characterizing the enhanced susceptibility of milky disease-infected scarabaeid grubs to entomopathogenic nematodes. Biol. Control 4: 67-73.

Trdan, S., M. Vidrih, N. Valic, and Z. Laznik. 2008. Impact of entomopathogenic nematodes on adults of Phyllotreta spp. (Coleoptera: Chrysomelidae) under laboratory conditions. Acta Agric. Scandinavica Sect. B - Soil and Plant Sci. 58: 169-175.

Turnock, W. J., and S. A. Turnbull. 1994. The development of resistance to insecticides by the crucifer flea beetle, Phyllotreta cruciferae (Goeze). Can. Entomol. 123: 1369-1375.

[USDA-NRCS] U.S. Department of Agriculture-Natural Resources Conservation Service. 2016. National Water and Climate Center. (http,// wcc.sc.egov.usda.gov/nwcc/view) (accessed 23 February 2016).

Ware, G. W. 1989. The pesticide book, 3rd ed. Thompson Publications, Fresno, CA.

Wei, H. Y, G. H. Wang, and X. F. Pang. 1992. Infectivity of the nematode, Steinernema feltiae, to the striped flea beetle, Phyllotreta striolata. J. South China Agric. Univ. 13: 26-29.

Xu, C., P. De Clercq, M. Moens, S. Chen, R. Han. 2010. Efficacy of entomopathogenic nematodes (Rhabditida: Sternenematidae and Heterorhabditidae) against the striped flea beetle, Phyllotreta striolata. BioControl 55: 789-797. 